\title{
Key Policies: Complete The Promise To Terminate Citarum Crisis
}

\author{
$1^{\text {st }}$ Badrudin Kurniawan \\ Department of Public Administration \\ Faculty of Social Science and Law \\ Universitas Negeri Surabaya \\ Surabaya, Indonesia \\ badrudinkurniawan@unesa.ac.id
}

\author{
$2^{\text {nd }}$ Tjitjik Rahaju \\ Department of Public Administration \\ Faculty of Social Science and Law \\ Universitas Negeri Surabaya \\ Surabaya, Indonesia \\ tjitjikrahaju@unesa.ac.id
}

\author{
$3^{\text {rd }}$ Muhammad Farid Ma'ruf \\ Department of Public Administration \\ Faculty of Social Science and Law \\ Universitas Negeri Surabaya \\ Surabaya, Indonesia \\ muhammadfarid@unesa.ac.id
}

\begin{abstract}
Citarum River has a vital role to local community. But people behavior is precisely to make it increasingly threatened due to heavy pollution and siltation of river. Various government policies have been carried out but it had not yet result expected goal. Based on this fact, author is interested to study Citarum River governance and provide relevant recommendations. This study uses library research approach. Either central government, provinces or regency has program to fix Citarum condition. This effort is already underway to three decades back. A variety of programs such as Kali Bersih (PROKASIH), Integrated Citarum Water Resources Management Investment , Citarum Bergetar and Citarum Bestari have been implemented. Those program rated less close to target. Some things that are considered to be the cause i.e. existence of overlapping regulation. In addition, those program have not been significant in reducing industrial waste pollution. Based on the findings, author recommends at least four major activities that need to be implemented, first, integrating government programs, secondly, rules on the management of toxic chemicals need to be fixed. Third, law enforcement must be strengthened. Fourth, provide an alternative livelihood for people of Citarum Watershed other than as an employee of the factory.
\end{abstract}

\section{Keywords-Citarum Crisis, River Governance, Key Policies}

\section{INTRODUCTION}

Citarum River is the third longest river on Java island after Bengawan Solo and Brantas River. Its long around 269 $\mathrm{km}$ and drains 12 regency. The location of the headwaters are in Mount Wayang, Bandung city and it flows toward Muara Gembong, Bekasi Regency. There are 5 watersheds (DAS) around the river such as Citarum, Cipunegara, Cilamaya, Cilalanang, and Ciasem. The river is also via a series of reservoirs Saguling, Cirata, and Jatiluhur and each dams water volume of 982 million $\mathrm{m}^{3}, 2,165$ million $^{3}$, and 3,000 million $\mathrm{m}^{3}$ [1]. Thus, such character make them have an important role for the life of local community.

Data that has been released by President of Indonesia confirmed the vital role of Citarum River. It is as water resources either for basic consumption or irrigation. About 27.5 million people in West Java and Jakarta rely on the surface water resources. Eighty percent $(80 \%)$ of population in Jakarta use it as drinking water and irrigation of 420 hectares of rice fields in Karawang and Indramayu. In addition, it it as flood control, aquaculture area and supplier of electric power amounted to 1,400 MW as well. Many people rely heavily on the sustainability of the river. But ironically, human behavior thus creating Citarum increasingly threatened [2].

Regional Office for the Citarum River Basin (Balai Besar Wilayah Sungai Citarum-BBWSC) has issued data regarding deforestation in river upstream area. In the span of only 9 years old, stands of trees in headwaters area has been declined precipitously. In 2000, the forest trees ranged up to 27,966 acres and year 2009 only 4,566 acres [3]. The area of forests converted to agricultural areas, industrial and residential. This land convertion run continously and makes upstream forest critical increasingly. Commander III Siliwangi on Indonesia National Army, Major General Doni Monardo said that 2,670 hectares in very critical condition and the rest is critically endangered [4].

Deamage of forested areas resulting soil eroded and sedimentation occurred. Citarum watershed is becoming increasingly shallow and flood prone, for example in Majalaya, Banjaran and Dayeuhkolot. Height of flood reached around 60 until 200 centimetres. Majority of the community looks surrender and accustomed to face recurrent floods each year. Although the public should often displaced due to the floods but that doesn't make them want to move somewhere to stay [5].

Rapid growth of industrial and residential areas in Citarum watershed also brings other problems up to now is failed to be resolved, i.e. water pollution. Upstrean Citarum Watershed is industrial area of Bandung and Cimahi. The middle part until downstream area are villages. Around the river flow which crosses the Karawang and toward the sea is an area of housing [2]. Citarum watershed inhabited about 15 million inhabitants and stands more than 3000 industries. Every day, the Citarum accommodates industrial waste, domestic waste, agricultural and farms waste. End of the year 2017 , it was recorded 20,462 tons of organic and inorganic waste dumped into Citarum. The river water is increasingly slovenly due to created as a giant toilet. Every day, tons of human feces and 35.556 tons of dung of cattle floated in the river [4]. This condition, which makes the Citarum get embarrassing predicate, that is, as the world's dirtiest rivers.

But not the embarrassing predicate which became serious issue. Large amount of disposal waste and rubbish from various sources cause river water becomes very toxic. Thousand factories that have dumped waste exceeded standard quality. Data form Environment Agency of West Java (Dinas Lingkungan Hidup Jawa Barat-DLH Jabar) showed 90 percent of 3,236 textile industries along the river do not have Waste Water Treatment Installation (Instalasi 
Pengolahan Air Limbah-IPAL) [6]. The results of clinical trials on water and fish, found a variety of harmful substances, such as mercury, Coliform, iron, manganese, lead, Sulfur, and chlorine. More deadly, also found a variety of harmful bacteria. The bacteria E-Coli derived from feces of livestock as well as human and Pseudomonas Aeroginosa allegedly derived from medical waste [4].

The community who occupied Citarum Watershed get negative impact due to dirty and toxic river water. Residents face clean water crisis. For decades, many of them have had to buy water for daily necessities. However, not all have access to clean water. The conditions forced them to utilize the dirty water that affected a lot of citizens suffered from disease. Based on data of top 10 diseases, Community Health Centers (Pusat Kesehatan Masyarakat-Puskesmas) in Majalaya and Cikaro note that community complained of skin disease, respiratory and digestive tract. Each year, the number of visits to Puskesmas reach 7,357 people [6].

Either Central Government, provinces or city/regency has had various Citarum River improvement program. This effort has been carried out since previous three decades and lasted until now. The initial improvement program based on Law (UU) Number 4 Year 1982 regarding Primary Provisions of Environmental Management. This act was later revised to Act Number 23 Year 1992 about Environmental Management and became the Law Number 32 Year 2009 about Protection and Management of the Environment. Rule change that has taken place is apparently still leaves the question of river siltation and heavy pollution. Based on this researcher interested in examining Citarum River Governance.

\section{RESEARCH METHODS}

This research can be categorized as research libraries because using materials such as books, journals, magazines and other library resources as the main data source [7]. This is not the kind of research requires researchers to search for data in the field. In addition, this type of research can be said to be a type of research that is able to facilitate various needs of researchers because it allows researchers to use components from other research methods.

Based on the type of data and its analysis technique, this research using a qualitative approach. Qualitative research results do not obtained through a statistical procedure or another calculation process. This approach directs researchers to elaborate, categorize and link variables examined in a narrative. Although some data can be calculated as well as census data but it is still analized qualitatively [8]. As for the data analysis, this research uses an interactive model. This research does not separate activities of data collection and data analysis [9]. Temporary data analysis results used by researcher as basis for next data collection.

In terms of its purpose, this research can be classified as applied research. The research was oriented on practical application of knowledge and importance of real problems that exist in the community [10].

\section{RESULTS AND DISCUSSION}

\section{A. The Long Way to Combat Citarum Crisis}

About three decades earlier, government has started Citarum River troubleshooting efforts. In 1989, government launched First Clean River Program (Program Kali BersihPROKASIH). The program aims to improve quality of water by using industrial waste treatment installation and domestic waste water management schemes. This program was implemented by provincial government, regency and city. Before the program was organized, a great flood struck Citarum River in 1986. This disaster is allegedly occurred due to enhancement of industrial development in the early 80-90s.

Next there is Citarum River Normalization Program. The program began in 1994 and applied by Regional Office for the Citarum River Basin (Balai Besar Wilayah Sungai Citarum-BBWSC). The government conducted a dredging, widening and straightening the meandering river water. As a result, have occurred straightening along the river approximately 70 kilometers. Then, in 2007, there is a Integrated Citarum Water Resources Management Investment Program (ICWRMIP). This program aims to improve the quality of rivers, addressing watershed problems, providing quality water supply and flood control. ICWRMIP includes 12 kabupaten/kota in West Java, with a total area of approximately 13,000 square kilometres. Then at the beginning 2017, Ministry of Environment and Forestry (Kementrian Lingkungan Hidup dan Kehutanan-KLHK) also budgeted Rp. 257 billion for rehabilitation of damaged land and forest in the upstream area of Citarum and Cimanuk [5].

Conceptually, program ICWRMIP requires involvement of many parties either cross-sector or cross-territory. In addition, the program also involves community participation. This is regulated in Act Number 7 Year 2004 about Water Resources. Then is also regulated in Regulation of Minister of Public Works Number 04/PRT/M/2008 concerning on Guidelines of Establishment for Coooordinating Body of Water Resource Management at the Provincial, City/Regency and watershed. It also provided in The Decision of Minister of Public Works Number 224/KPTS/M/2013 about Formation of Team Coordinating Water Resources Management for Citarum Watershed. But in fact, synergy does not occur between the ministries and relationship of centre government with local government. Each government concerns only on program itself. In addition the government has not yet firmly crack down on industries that dispose of waste without any processing [11].

Not only central government, local governments were also attempting to address Citarum River crisis. Government of West Java Province, in 2001, started Citarum Bergetar Program (Clean, Beauty and Sustainably). Within framework the program, provincial government created a team for investigating Citarum Watershed problems. Then it formed action plan to control damage, watershed conservation and restoration of pollution, as well as community empowerment. In fact, Watershed Citarum is indeed dealt with many parties, namely central government, provincial, regional, and local government and state-owned enterprises. However, the success rate of program is unknown. The existence of overlapping regulation is suspected to be the cause [12]. 
Poor condition of river encourages provincial government continues to deliver programs of improvement the river condition. In 2013, Citarum Watershed Forum formed until then changed its name to Citarum Bestari (clean, healthy, beautiful and sustainably) in 2014. This program seeks to address issue of domestic garbage in Citarum. Provincial government invite and educate local community to be wise for processing waste. According to Head of Local Department of Environment (DLH) of West Java Province, Anang Sudarna, garbage disposal per day decrease until $50 \%$. However, Governor of West Java also does not deny that the efforts of controlling industries that dump waste carelessly have been not success yet [13].

Based on previous research on sustainability of water pollution control in Citarum river also note there are still many problems in repair quality of the river. This research was conducted starting in 2012 to 2015 and its respondent include government, environmental experts, environmental practitioners, consultants and practitioners. This research focus on several dimensions which have an important role in maintaining sustainability of environmental protection and preservation effort. Such dimensions include policy, technical work, economic, socio-cultural, law enforcement and stakeholder support.

This research result shows that policy dimension illustrates poor quality of implementation of water pollution control. This is allegedly due to each institutions did not sinergyze each other. Technical dimensions describing difficulties of implementation of local regulations on Liquid Waste Standard Quality (Baku Mutu Limbah Cair-BMLC) in areas of dense settlement and industries. In this region, water pollution load capacity has been exceeded. Socialization of infiltration wells is often done but not many that do. Construction of dam is difficult because of spend large costs and need a very broad area. Technology of Waste Water Treatment Installations (IPAL) is very expensive. Waste waster claim already meets BMLC without thinking that river condition is already severe polluted. Dimensions of economy showed that lack of funding for cost recovery of affected areas. Besides, people who live on riparian hasn't been able to take benefit from the waste they produce. Dimension of socio-culture found that concern of riparian toward environment is still low. Then, law enforcement dimension describes that clarity of regulation is quite good but law enforcement is still weak. Next dimension i.e. stakeholder support. From this dimension looks that lack of support from stakeholders to protect and preserve environment [14].

\section{B. Mutual Steps to End Citarum Crisis}

Trillions dollars to resolve Citarum River crisis have been allocated either by central government or local governments. Amount of these funds is not only come from government itself but also debt of other parties such as Asian Development Bank (ADB). A variety of programs with a variety of names have also been carried out and still ongoing. However, condition of river is still dirty and toxic. This is confirmed by Head of Pollution Division of Environmental Agency in West Jawa Province, Eva Fandora, in 2017, that quality of Citarum entered in classification of second class (heavy pollution). In addition, the floods also still continues to occur mainly in several subdistricts of Bandung Regency [5].

Starting February 2018, central government organized a Program of Citarum Harum. President of Joko Widodo (Jokowi) assess Citarum is not resolved yet because government agency programs were not integrated yet. Citarum Harum will involve many parties. This is contained in Presidential Regulation Number 15 Year 2018 on Accelerating Control of Pollution and Damage in Citarum River Basin. This regulation governs formation of Citarum Watershed Team consisting of, directors and task force. Directors is composed ministers while the task force is composed of Governor of West Java, Commander of Kodam III/Siliwangi, Commander of Kodam Jayakarta, Head of West Java Police, Chief Prosecutor of West Java Province, Head of Jakarta Metropolitan Police. As the Task Force Commander, governor can appoint a team of experts to perform the task [15].

Director's duties are also listed in Presidential Regulation Number 15 Year 2018. Directors have a duties as follows (1) sets out integrated and sustainable policy of controlling pollution and damage in Citarum Watershed; and (2) provide direction in implementation of Task Force job, including the consummation, removal, and/or replacement of provisions of regulation which does not support or hinder efforts of Citarum Watershed control, and to take social impact mitigation which arise as along as Citarum Watershed control efforts.

The implementation of pollution prevention and Citarum Watershed damage handling, task force conducted a series of activities. Some of the activities in question i.e.

- socialization and education by providing caution information of pollution and damage impact toward Citarum Watershed;

- handling of waste and restoration of ecosystems;.

- coordinate relocation of affected communities in Citarum Watershed;

- coordinating with related institutions in data update and needed information is as an effort to combat the pollution and Citarum Watershed damage

- generating an innovation in tackling pollution and Citarum Watershed damage in accordance with development of science and technology;

- community empowerment; and prevention and law enforcement.

Since enactment of Presidential Regulation seemed several activities have been carried out namely tree planting action was done in Citarum upstream. Then waste evacuation action from the river was done as well. This action is carried out by Kodam III/Siliwangi. Beside waste clean-up action, Kodam III/Siliwangi also provide education to community in some villages about preservation of ecosystems and repair Citarum [16]. Minister of Research, Technology and Higher Education (Menristekdikti), Mohamad Nasir also launched a program of Citarum Harum Thematic Community Service Program (Kuliah Kerja Nyata-KKN) at Padjadjaran University in Bandung. This is the first step because the minister will engage entire college in West Java and Jakarta 
for the implementation of this program [17]. Cooperation among Environmental Agency of West Java Province, and Kodam III Siliwangi do unannounced inspection to 39 factories in Bandung. The result is waste from 13 factories exceeded standard quality. These results are then given to regency/city governments, as giver of license, to immediately followed up [6].

Enforcement of Presidential Regulation Number 15 Year 2018 by President is a right step. In the regulation involve a great many stakeholders. Government is aware that the handling of the issue might not be resolved by government only. Therefore public participation in addressing the problem of Citarum also noted in regulation. Community can participate in prevention efforts, tackling pollution and damage, as well as the restoration of Citarum Watershed. Society referred to consist of individuals, community organizations, religious organizations, philanthropy, businessmen, academics, and other stakeholders.

Concept of the program is not much different with ICWRMIP i.e. various stakeholders, either cross-sector or cross-region were involved. Unfortunately, implementation of Citarum Harum Program more exposes role of Indonesia National Armed Forces (Tentara Nasional Indonesia-TNI) in action clean-up litter, planting plants and conduct unannounced inspection to industries. Strategic activity for addressing the issue have not been seen. For example, government have not built a solid network yet to align all programs either cross-ministerial and cross-region.

Necessarily Presidential Regulation Number 15 Year 2018 was able to give a strong impetus to realize integrated program. Over the time, solution for Citarum crisis couldn't work optimally because each institution out of sync. The idea of a Gendong Pipe from Ridwan Kamil to cope with domestic waste hindered because the River Citarum cliffs is the authority of the Ministry of Public Works (Kemen PU). The minister has program to dredge sedimentation due to land conversion in upstream area. Unfortunately, Ministry of Forestry and Perhutani could not prevent exploitation of forests. Dredging cost trillions of rupiah but sedimentation is running constantly [18]. For example, a working institution sync step i.e. program Eco Village provincial Government Program be integrated with Tematic Community Service Program which is initiated by Kemristekdikti.

Other fundamental issues also need special attention such as law enforcement for industrial polluters. But along with law enforcement, Greenpeace Indonesia Spokesman, Ahmad Ashov, said that rules on management of toxic chemicals needs to be fixed. Many of chemicals that are in Citarum but is not regulated by government. Second, encouraging law enforcement must be strengthened. Coordinator of Elingan Community, Deni Riswandini mentions that it is repeatedly reported alleged pollution by factories, but no follow-up from law enforcer. In addition it also often experience a dead-end in court even though it has enough evidence [19].

Coordinator Minister of Maritime, Luhut Binsar Pandjaitan confirmed that he would crack down industry which dispose waste without any processing. He was appointed Chairman of Director in Citarum Watershed Team. In a chance, Luhut guarantee that whoever the perpetrators, no matter big or small, which pollute Citarum will be dealt with firmly. In fact he also risked his position in favor of addressing the Citarum crisis [20].

Lastly, need an effort to provide an alternative livelihood for local people in Citarum Watershed. The community actually understand negative impact of waste factories dumped into the river. But they are not powerless against because they depend on the existence of industries. Many of those who work as employees of the factories. Therefore it needs a long-term effort to erode their dependence. Communities need to be given alternative jobs that are environmentally friendly. For example, in the long run, the river Citarum is designed as one of tourist destinations of nature-friendly environment. Although the Ministry of Tourism are not entered in Citarum Watershed Team but could be involved. Identification of potential River for tourism needs to be done. The community was accompanied to manage river tourism. Alternative river tourism can be developed in addition to support the development of sustainable fisheries in the Citarum Watershed by the Ministry of Marine and Fisheries.

\section{CONCLUSION}

Citarum River as the third longest river in Java has a very vital role for local communities. The river is a water source either for consumption or irrigation. In addition, Citarum as a flood control, aquaculture area and supplier of electric power. Ironically, human behavior is precisely to make the functions increasingly threatened due to siltation and heavy pollution. Various government policies has been done. Either central government, provinces or regency/city has Citarum River improvement program. But many programs that have been undertaken have not reached optimally the target.

Citarum Harum program gives space for all levels of government for synergizing all programs. In addition, the community and the private sector also has an important role to resolve Citarum problems. This has been arranged in Presidential Regulation Number 15 Year 2018 on Accelerating Control of Pollution and Citarum River Watershed Damage.

Based on Presidential Regulation, activities in Citarum Harum program involve various stakeholders. But so far, the implementation of this program has not yet touched the root of issue. Various activities that need to get more attention namely, First, integrating government programs, either crosssectoral or cross-territory. Second, regulation on management of toxic chemicals needs to be fixed. Many of chemicals are in Citarum is not regulated by Government. Third, law enforcement should be strengthened. Lastly, provide an alternative livelihood for people of Citarum Watershed. This is to reduce the dependence of community toward industries are not eco-friendly.

\section{ACKNOWLEDGMENT}

The authors would like to thank Galih W. Pradana for his careful review and suggestions which helped to improve this editorial.

\section{REFERENCES}

[1] M. F. Imansyah, "Overview of Citarum Watershed Problems and Solutions as well as Government Policy Analysis," J. sosioteknologi, 
vol. 25, no. April, 2012.

[2] E. B. Raharta, "Citarum River Basin Revitalization: EconomicalEcological Tree \& 'Social-Capital,”' 2018. [Online]. Available: http://www.stagingpoint.com/read/2018/03/03/213225/Revitalisasi.DAS.Citarum.Pohon. Ekonomis-Ekologis.Social-Capital. [Accessed: 17-May-2018].

[3] E. R. Hartati, "Citarum Revitalization Encourage Potentially the Economy," $2018 . \quad$ [Online]. Available: http://www.beritasatu.com/satu/480952-revitalisasi-citarumberpotensi-gerakkan-ekonomi.html. [Accessed: 16-May-2018].

[4] Y. Saputra, "The Big Mission Overcomes Pollution in the Citarum River," $2018 . \quad$ [Online]. Available: https://www.rappler.com/indonesia/berita/194162-misi-besar-atasipencemaran-sungai-citarum. [Accessed: 13-May-2018].

[5] D. Iqbal, "Trillions of Rupiah Disbursed, But Citarum River Basin Remains Damaged. Why?," $2017 . \quad$ [Online]. Available: http://www.mongabay.co.id/2017/04/07/triliunan-rupiah-telahdikucurkan-tapi-das-citarum-tetap-rusak-kenapa/. [Accessed: 18May-2018]

[6] D. Iqbal, "Unending Waste Poisoning the Citarum River (Part 1)," 2018. [Online]. Available: http://www.mongabay.co.id/2018/02/26/limbah-yang-tak-pernahhenti-meracuni-sungai-citarum-bagian-1/. [Accessed: 15-May-2018]

[7] Y. Wahyudin, "Humanistic Learning Theory of Carl Ransom Rogers and Its Implications for Teaching Methods of Islamic Education," State Islamic University Sunan Kalidjaga, 2009.

[8] A. Strauss, Basics of Qualitative Research: Procedures and Techniques. Yogyakarta: Pustaka Pelajar, 2009.

[9] B. Bungin, Qualitative Research Data Analysis: The Philosophical and Methodological Understanding towards Model Application Mastery. Jakarta: Rajawali Press, 2012.

[10] S. Bartolini, "Pure and Applied Research: Striking a Balance," Fiesole, 2011

[11] Dina, "Evaluation of Integrated Citarum Water Resources Management Investment Program (Study Case on Citarum Wateshed Upstream, Bandung Regency)," Acad. Praja, vol. 1, no. 1, pp. 85$110,2018$.

[12] D. Iqbal, "Citarum Harum, Government's Optimistic Step to Restore the Triumph of Citarum River (Part 3)," 2018. [Online]. Available: http://www.mongabay.co.id/2018/02/28/citarum-harum-langkah- optimis-pemerintah-pulihkan-kejayaan-sungai-citarum-bagian-3/. [Accessed: 17-May-2018].

[13] S. Mochammad, "East Java Provincial Department of Environmental: Citarum Bestari Successfully Reduces River Waste 50 Percent," 2017. [Online]. Available: https://news.detik.com/berita-jawa-barat/d3565168/dlh-jabar-citarum-bestari-berhasil-kurangi-sampah-sungai50-persen. [Accessed: 26-May-2018].

[14] I. A. Yusuf, "Analysis of Water Pollution Control in the Upper Citarum River Zone Using Multi Dimensional Scalling Model," $J$. Sumber Daya Air, vol. 12, no. 1, pp. 17-32, 2016.

[15] J. Widodo, Presidential Regulation of Number 15 Year 2018 on Acceleration of Controlling Pollution and Citarum Watershed Damage. Indonesia, 2018, pp. 1-10.

[16] A. Warsudi, "Citizen Education on Citarum Harum, Kodam Gives 1,400 Personnel," 2018. [Online]. Available: https://daerah.sindonews.com/read/1279858/21/edukasi-wargatentang-citarum-harum-kodam-kerahkan-1400-personel-1517909224. [Accessed: 27-May-2018].

[17] Indriani, "The Ministry of Research, Technology and Higher Education Launches Thematic Community Service Program 'Citarum Harum,"” $2018 . \quad$ [Online]. Available: https://www.antaranews.com/berita/706754/kemristekdiktiluncurkan-kkn-tematik-citarum-harum. [Accessed: 27-May-2018].

[18] Anonymous, "The Citarum Dream is Worth Taking," 2018. [Online]. Available: https://kolom.tempo.co/read/1083980/impian-citarumlayak-diminum. [Accessed: 27-May-2018].

[19] M. Asmail, "A Set of Ways to Smell the Scent of Citarum River," 2018. [Online]. Available: https://www.aa.com.tr/id/headlinehari/setumpuk-cara-demi-mencium-harum-sungai-citarum-/1095840. [Accessed: 27-May-2018]

[20] R. Satrianegara, "Luhut Bets Position For Citarum Harum," 2018. [Online]. Available: https://www.cnbcindonesia.com/news/20180406195650-410045/luhut-pertaruhkan-jabatan-demi-citarum-harum. [Accessed: 27-May-2018]. 